Dept. of Animal Production,

Faculty of Science and Technology of Animal Production,

Sudan University of Science and Technology, Khartoum North (Kuku), Sudan

Email: www.sustech.edu

\title{
THE FEEDING VALUE OF FODDER BEET (BETA VULGARIS VAR.CRASSA) VERSUS FODDER SORGHUM ABU SABEIN (SORGHUM BICOLOR L. MOENCH) UNDER SUDAN CONDITIONS
}

(With 9 Tables and 2 Figures)

By

\section{MUNA E. KHOGALI; Y.M.I. DAGASH* and M.G. EL-HAG ${ }^{* * *}$}

* Department of Field Crops Sciences, Faculty of Agricultural Studies, Sudan University of Science and Technology, Shambat, Sudan, Email: www.sustech.edu

** Department of Animal Production, Faculty of Agriculture, Al Zaiem Alazhary University, Khartoum North, Sudan

(Received at 20/10/2010)

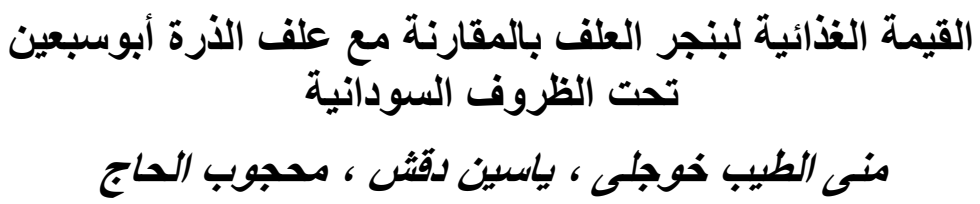

خلاصة الأطروحة تم تقويم القيمة الغذائية لبنجر العلف مقارنة مع علف الذرة أبوسبعين خلال

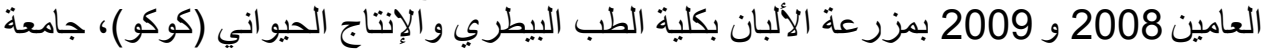

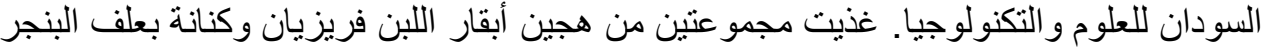

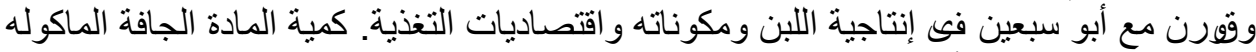

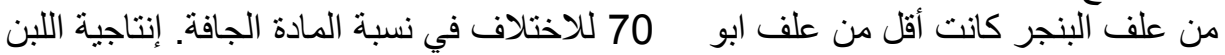

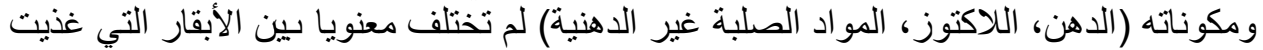

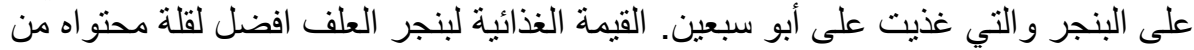

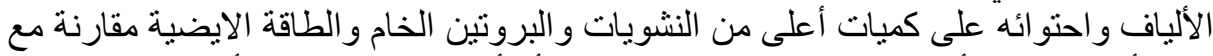

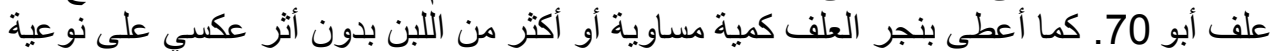
اللبن بالرغم من قلة المادة الجافة المأكولة من البنجر مقارنة مع أبر أبو

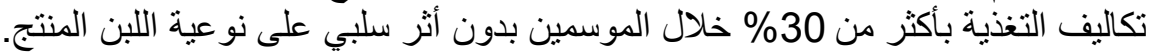
كلمات مفتاحية: القيمة الغذائية، بنجر العلف، إنتاجية اللبن، نوعية اللبن، إقتصاديات التغذية.

\section{SUMMARY}

The feeding value of fodder beet (Beta vulgaris var.Crassa) was compared to fodder sorghum Abu 70 (Sorghum bicolor L. moench) in the two successive seasons (2008 and 2009), at the milk farm of the Faculty of Veterinary Medicine and animal Production (Kuku), Sudan University of Science and Technology. Both fodders were fed to two separate groups of 
cross-bred (Frisian X Kenana) milking cows and their impact on feed intake, milk yield, milk composition and economics of feeding was examined. Neither milk yield $(8.65 \mathrm{Kg}$ vrsus8.67) nor its composition [fat $(3.55 \%$ versus $3.45 \%)$, lactose $(4.52 \%$ versus $4.56 \%)$ and solids-non fat $(8.54 \%$ versus $8.57 \%)$ ] showed significant differences ( $>0.05)$ between cows fed on beet and those fed on Abu 70. The nutritive value of beet forage was better than Abu70 in terms of low CF content, high amounts of NFE (carbohydrates), CP and ME. The feeding value of beet forage was by far superior to $\mathrm{Abu} 70$ as reflected in the lower DM intake and equal or superior yields of milk by cows fed on beet without any adverse effects on milk quality. Feeding costs decreased significantly along the two seasons by $>30 \%$ when cows fed on fodder beet.

Key words: Feeding value, Fodder beet, Feed intake, Milk yield, Milk quality, Nutritive value.

\section{INTRODUCTION}

Fodder beet (Beta vulgaris var.Crasa), a member of the chenopodiaceae family (www.ars-grin.gov, 1987), is also known as mangel (Martin, 1976). It is World-wide in temperate zones up to $55^{\circ} \mathrm{N}$ (www.biolaie.uni-hambura.de, 2006).

The feeding value of forage is defined as its capacity to promote animal production and depends upon its ability to supply nutrients to the animal (Beever et al., 2000). Green fodders are very important in dairying as it is a source of carotene, the precursor of vitamin A, and calcium (Abd Alrahman and Ahmed, 2005). Feeding as a whole represents $75 \%$ of the total cost of milk production in the developing countries (Mahesh, 1999).

In the Sudan, the cost of feeding dairy cattle constituted about $80 \%$ of total cost of the milk production (Hussein, 2008). According to AOAD (2002) the feeding cost of dairy farms can be minimized by feeding low yielding and dry animals green fodders (maintenance ration). Cattle are regarded as the main source of milk production in the Sudan as they produce about $80 \%$ of the total milk output in the country (Animal Wealth Bank, 2003).

Fodder sorghum (Sorghum bicolor L. Moench) cultivar Abu 70, the main cereal forage in the Sudan, is a warm season crop. Despite that it is grown untimely during the winter in Khartoum State (Abuswar, 2005) and along the banks of the Blue Nile and the white Nile (Khair et al., 2003). Being a summer crop, forage yield of Abu70 is suboptimal when sown in winter in Khartoum (Kambal, 1983). 
For maintenance ration dairy cattle around cities like Khartoum are fed either green forages or crop residues or both (Khair et al., 2003). Such feeding system necessitates all year round forage production.

Fodder beet is popular in many countries such as United States of America, Denmark, Netherland, Syria and Egypt due to its high yield which is estimated to be more than 80 t/ha under favorable conditions. Fodder beet is also tolerant to salinity and performs well under saline soils (Shalaby et al., 1989) with an average yield of about 40-50 t/ha in 60-80 days (Anonymous, 1994). It contains 10-15\% dry matter and may yield 20 $\mathrm{t} /$ ha of dry matter in one harvest as compared to 13-15 t/ha from four cuts of grass (Kiely et al., 1991). In Egypt, its area was increased in the last few years for animal feeding as a fresh material or to be conserved as silage during summer season, in which shortage of green and succulent forage occurs (Abu El Hassan, et al., 1971). Fodder beet tops and roots are succulent, palatable and easily digestible and liked by most livestock (Chatterjee and Das, 1989). It is of high nutritional value and a good source of energy for animals (Ibrahim, 2005). Its content of carbohydrates is about 71.69\% dry matters (Abdallah and Yassen, 2008).

Fodder beet is a good forage especially during the critical period of forage shortage such as early summer season in the Sudan. Fodder beet crop is not common in the Sudan and there is no scientific research concerning its production under Sudan conditions.

The objectives of this research is to evaluate the feeding value of fodder beet compared to fodder sorghum (CV. Abu 70) for dairy cows in terms of nutritive value, feed intake, milk yield, milk composition and economics of feeding.

\section{MATERIALS and METHODS}

Location: Two feeding trials were conducted at the milk farm of the Faculty of Veterinary Medicine and Animal Production, Sudan University of Science and Technology at Kuku, in the two successive seasons (2008 and 2009). The feeding value of fodder beet in terms of feed intake, milk yield, milk composition (fat, lactose and solids non-fat percentages) was evaluated. The economics of feeding compared to that of forage sorghum cultivar Abu 70 was determined. Feeding trial 1 was carried out from 16/330/4/2008 and trial 2 from 11/3- 25/4/2009.

Experimental Animals: Ten dairy cattle, cross-bred (Frisian X Kenana) were used in each feeding trial. The cows were in the second stage of lactation. The experimental cows were divided into two groups (control 
group and test group) of five animals each, depending on their milk yield (giving more or less an equal average milk yield/head/day).

Housing: The experiments were carried out in an open-sided, half shaded shelter house with bamboo, thatch and ground floor with an area of $18 \mathrm{~m}^{2}$ /cow. The cows were housed individually in pens $(3 \mathrm{~m} \times 6 \mathrm{~m})$, each equipped with two half barrel feed troughs, one for green forage and other for the concentrate.

Experimental Design: A completely Randomized Design (CRD) of two treatments and five cows (replications) per treatment was used.

Feeds and Feeding: The experimental feeds were fodder beet, fodder sorghum Abu 70 and concentrate mixture on as fed basis (Table1).

Table 1: Composition (as-fed) of the commercial concentrate ration (Dairy-16) fed to dairy cows during the two feeding trails (2008 and 2009)

\begin{tabular}{|c|l|c|}
\hline \multicolumn{2}{|c|}{ Concentrate Mixture } & $\%$ \\
\hline 1 & Ground sorghum grains & 27.10 \\
\hline 2 & Wheat Bran & 12.50 \\
\hline 3 & Ground-nut Seed Cake & 11.10 \\
\hline 4 & Sun Flower Seed Cake & 10.00 \\
\hline 5 & Ground-nut Seed Hulls & 27.10 \\
\hline 6 & Molasses & 7.80 \\
\hline 7 & Limestone & 2.40 \\
\hline 8 & Salt $(\mathrm{NaCl})$ & 0.70 \\
\hline 9 & Urea(Fertilizer grade) & 1.30 \\
\hline
\end{tabular}

The cows were allocated to two dietary treatments: twenty kilograms of fresh fodder beet was given to the treated group at a ratio of two parts of tubers: one part of leaves $(13.3 \mathrm{Kg}$ tubers and $6.7 \mathrm{Kg}$ leaves) weighed separately and mixed together prior to feeding in one feed trough. Beet tubers were chopped manually using a sharp knife. The control group was fed on twenty kilograms of fodder sorghum cultivar Abu 70. The green fodders (beet and Abu 70) were offered once a day at $10.00 \mathrm{a} . \mathrm{m}$.

Concentrate supplements $(7 \mathrm{~kg} / \mathrm{head} / \mathrm{day})$ were given to both groups twice a day at milking time (i.e. 8.00 a.m. and 4.00 p.m). The cows had ad libitum access to water and minerals licks throughout the duration of the trails.

The adaptation period lasted for four days. The experimental feeding period was six weeks. The cows were weighed at the beginning and end of the experiments using a $1000 \mathrm{Kg}$ balance graded at $0.02 \mathrm{Kg}$ per point. 
Sampling and Chemical Analysis: Daily milk yield $(\mathrm{kg})$ of both groups were recorded in the morning and evening, using buckets and a hooked scale balance ranging from 0 to $25 \mathrm{Kg}$ and graded at $0.1 \mathrm{Kg}$ per point.

Feed samples of beet leaves and tubers, sorghum Abu 70 and concentrate were taken weekly and chemically analyzed according to AOAC (1984) for dry matter (drying at $105^{\circ} \mathrm{C}$ for 24 hours). The samples were pooled to represent the feeding period, then they were ground and stored in glass bottles for subsequent analysis (at amount of $100 \mathrm{~g} / \mathrm{bottle}$ of bulked samples). Ash was estimated by ashing at $550^{\circ}-600^{\circ} \mathrm{C}$ for three hours, crude protein $(\mathrm{CP})$ by the Kjeldahl method, crude fiber, ether extract and N.F.E by difference (NFE\% $=100-(\mathrm{CP} \%+\mathrm{CF} \%+\mathrm{EE} \%+\mathrm{Ash} \%)$.

Milk samples for chemical composition were collected from morning milk. Three samples from each group were collected in glass bottles and kept at $4^{\circ} \mathrm{C}$ for milk analysis. Milk composition was determined every two weeks throughout the experimental period for fat, lactose and solids non-fat(SNF) percentages by Ecomilk Ultrasonic Milk Analyzer (Eon Trading LLC,USA, Bulgaria Office Industries) in the first trail and lactoscan 90 Milk Analyzer (ALPES INDUSTRIES SERVICES, milk Otronic Ltd.) in the second one.

Statistical Analysis: Data for both feeding trials were statistically analyzed as Completely Randomized Design (CRD) by standard analysis of variance (ANOVA). Treatments means were separated by the Least Significant Difference (LSD) method at 5\% level according to Gomez and Gomez (1984) using MSTAT Computer Program v.4 (1986).

\section{RESULTS}

Nutrients and chemical composition of the feed (quality): The proximate analysis (DM basis) and energy contents of the roughage feed stuffs and dairy concentrate ration fed to dairy cows during the two feeding trials (2008 and 2009) is presented in Table (2). Generally, there were no differences in nutrients composition between the two feeding trials for the different types of feeds. The results indicated that the tubers were rich in starch (NFE) and low in crude protein (CP), crude fibre (CF) and ash (ASH), compared to leaves. However, beet tubers were similar in ether extract (EE) to the leaves. Dry matter content (DM) was very low in leaves and tubers; it ranged between 13.03 and $15.30 \%$ as compared to that of fodder sorghum Abu 70 (31.5-33.0\%). The results also revealed that fodder sorghum Abu 70 was lower than fodder beet leaves in crude protein (CP) and ash (ASH), higher in crude fibre (CF), similar in ether extract (EE), higher in NFE than beet leaves and lower than. 
Table 2: Proximate analysis (DM - Basis) and energy content of the roughage feed stuffs and dairy concentrate ration fed to dairy cows during the two feeding trials (2008 and 2009).

\begin{tabular}{|c|c|c|c|c|c|c|c|c|}
\hline \multirow{2}{*}{$\begin{array}{c}\text { Nutrient } \\
\begin{array}{c}\text { composition } \\
\%\end{array}\end{array}$} & \multicolumn{7}{|c|}{$\begin{array}{c}\text { Fodder beet } \\
\text { leaves }\end{array}$} & \multicolumn{2}{c|}{$\begin{array}{c}\text { Fodder beet } \\
\text { tubers }\end{array}$} & \multicolumn{2}{c|}{$\begin{array}{c}\text { Fodder sorghum } \\
\text { Abu 70 }\end{array}$} & \multicolumn{2}{c|}{$\begin{array}{c}\text { Commercial } \\
\text { concentrate } \\
\text { ration (D.16) }\end{array}$} \\
\cline { 2 - 10 } & 2008 & 2009 & 2008 & 2009 & 2008 & 2009 & 2008 & 2009 \\
\hline DM & 13.80 & 13.03 & 15.30 & 14.50 & 33.00 & 31.50 & 96.10 & 94.40 \\
\hline CP & 11.20 & 11.90 & 6.40 & 6.95 & 6.30 & 6.75 & 18.00 & 17.75 \\
\hline CF & 11.25 & 11.35 & 6.75 & 6.50 & 27.50 & 25.50 & 10.60 & 10.50 \\
\hline EE & 2.26 & 2.25 & 2.33 & 2.35 & 2.30 & 2.40 & 3.79 & 4.70 \\
\hline Ash & 23.70 & 23.50 & 12.50 & 11.75 & 6.09 & 6.55 & 9.09 & 9.25 \\
\hline NFE & 51.59 & 51.00 & 72.02 & 72.45 & 57.81 & 58.80 & 58.52 & 57.80 \\
\hline Calculated ME* & 9.8 & 9.8 & 11.9 & 12.0 & 10.9 & 11.1 & 12.1 & 12.2 \\
\hline MJ/kg DM) & & & & & & & & \\
\hline
\end{tabular}

* ME was calculated according to the equation given by MAFF (1975) as follows:

$\mathrm{ME}(\mathrm{MJ} / \mathrm{kg} \mathrm{DM})=0.012 \mathrm{CP}+0.031 \mathrm{EE}+0.005 \mathrm{CF}+0.014 \mathrm{NFE}$

tubers. Calculated energy content of fodder beet leaves and tubers were about 9.8 and $12.0(\mathrm{MJ} / \mathrm{kg} \mathrm{DM}) \mathrm{ME}$, respectively, as compared to 11 (MJ/kg DM) ME for sorghum Abu 70.Table (3) shows the major mineral profile of beet, Abu 70 forages (DM. basis) and salt lick-block composition. Fodder beet was higher in both $\mathrm{Ca}(0.55 \%)$ and $\mathrm{P}(0.21 \%)$ as compared to $0.44 \%$ and $0.01 \%$ for $\mathrm{Ca}$ and $\mathrm{P}$ of fodder sorghum Abu70, respectively.

Dry matter intake: Table (4) summarizes daily feed intake of dairy cows fed on beet versus fodder Abu 70 as roughages, supplemented with a fixed amount of dairy concentrate in the two feeding trials (2008 and 2009). Mean daily DM intake of beet, sorghum Abu 70 and commercial concentrate for the two feeding trials were 2.95, 6.60, 6.73, and 2.80, 6.30, $6.61 \mathrm{Kg} \mathrm{DM} /$ day, respectively. The dairy cows fed on beet consumed about 9.68 and $9.41 \mathrm{~kg}$ DM per day while those fed on sorghum Abu 70 consumed about 13.33 and $12.91 \mathrm{~kg}$ DM per day for the two feeding trials, respectively. 
Table 3: Major mineral profile of beet, Abu 70 forages* and salt-lick block composition $^{* * *}$.

\begin{tabular}{|c|c|c|}
\hline On dry matter basis & $\mathrm{Ca} \%$ & $\mathrm{P} \%$ \\
\hline Fodder beet $*$ (DM 11\%) & 0.55 & 0.21 \\
\hline Fodder sorghum Abu $70 * *($ DM $28 \%)$ & 0.44 & 0.01 \\
\hline \multicolumn{3}{|c|}{ Mineral Block ${ }^{* * * *}$} \\
\hline Composition & \multicolumn{2}{|c|}{ Value } \\
\hline Sodium & \multicolumn{2}{|c|}{$35.7 \%$} \\
\hline Calcium & \multicolumn{2}{|c|}{$0.2 \%$} \\
\hline Phosphorus & \multicolumn{2}{|c|}{$0.0 \%$} \\
\hline Magnesium & \multicolumn{2}{|c|}{$1.3 \%$} \\
\hline Manganese & \multicolumn{2}{|c|}{$750 \mathrm{mg} / \mathrm{Kg}$} \\
\hline Cobalt & \multicolumn{2}{|c|}{$25 \mathrm{mg} / \mathrm{Kg}$} \\
\hline Iodine & \multicolumn{2}{|c|}{$38 \mathrm{mg} / \mathrm{Kg}$} \\
\hline Zinc & \multicolumn{2}{|c|}{$2500 \mathrm{mg} / \mathrm{Kg}$} \\
\hline Iron & \multicolumn{2}{|c|}{$400 \mathrm{mg} / \mathrm{Kg}$} \\
\hline Selenium & \multicolumn{2}{|c|}{$13 \mathrm{mg} / \mathrm{Kg}$} \\
\hline Copper & \multicolumn{2}{|c|}{$350 \mathrm{mg} / \mathrm{Kg}$} \\
\hline
\end{tabular}

* Values were obtained for averages of beet leaves and tubers.

** Values were taken from Ellis (1981).

*** Values were given by Terrassa (Barcelona)-SPAIN-Manufacture specifications company Ltd.

Table 4: Daily feed intake of dairy cows fed on beet versus sorghum Abu 70 as roughages, supplemented with a fixed amount of dairy concentrate in the two feeding trials (2008 and 2009).

\begin{tabular}{|c|c|c|c|c|c|c|c|c|}
\hline \multirow{4}{*}{ Item } & \multicolumn{8}{|c|}{ Type of diet } \\
\hline & \multicolumn{4}{|c|}{2008} & \multicolumn{4}{|c|}{2009} \\
\hline & \multicolumn{2}{|c|}{ Fodder beet } & \multicolumn{2}{|c|}{ Abu 70} & \multicolumn{2}{|c|}{ Fodder beet } & \multicolumn{2}{|c|}{ Abu 70} \\
\hline & Beet & Conc. & Abu70 & Conc. & Beet & Conc. & Abu 70 & Conc. \\
\hline $\begin{array}{l}\text { Mean daily intake as } \\
\text { fed (kg/head/day) }\end{array}$ & $20 *$ & 7 & 20 & 7 & $20 *$ & 7 & 20 & 7 \\
\hline Overall intake & \multicolumn{2}{|c|}{27} & \multicolumn{2}{|c|}{27} & \multicolumn{2}{|c|}{27} & \multicolumn{2}{|c|}{27} \\
\hline $\begin{array}{l}\text { DM intake } \\
\text { (Kg/head/day) }\end{array}$ & 2.95 & 6.73 & 6.60 & 6.73 & 2.80 & 6.61 & 6.30 & 6.61 \\
\hline $\begin{array}{l}\text { Total DM intake } \\
\text { (Roughages + Conc.) }\end{array}$ & \multicolumn{2}{|c|}{9.68} & \multicolumn{2}{|c|}{13.32} & \multicolumn{2}{|c|}{9.41} & \multicolumn{2}{|c|}{12.91} \\
\hline $\begin{array}{l}\text { Average initial body } \\
\text { weight }(\mathrm{kg})\end{array}$ & \multicolumn{2}{|c|}{434.3} & \multicolumn{2}{|c|}{387.8} & \multicolumn{2}{|c|}{459} & \multicolumn{2}{|c|}{473} \\
\hline $\begin{array}{l}\text { Average final body } \\
\text { weight }(\mathrm{kg})\end{array}$ & \multicolumn{2}{|c|}{432.9} & \multicolumn{2}{|c|}{407.9} & \multicolumn{2}{|c|}{454} & \multicolumn{2}{|c|}{453} \\
\hline $\begin{array}{l}\text { Average body weight } \\
(\mathrm{kg})\end{array}$ & \multicolumn{2}{|c|}{433.45} & \multicolumn{2}{|c|}{397.85} & \multicolumn{2}{|c|}{456.5} & \multicolumn{2}{|c|}{463.0} \\
\hline $\begin{array}{l}\text { Average body weight }{ }^{0.75} \\
\text { (kg) (Metabolic B.wt) } \\
\left(\text { Ave W) }{ }^{0.75}\right.\end{array}$ & \multicolumn{2}{|c|}{95.0} & \multicolumn{2}{|c|}{89.0} & \multicolumn{2}{|c|}{98.8} & \multicolumn{2}{|c|}{99.8} \\
\hline DM Intake $\mathrm{g} / \mathrm{kg} \mathrm{W}^{0.75}$ & \multicolumn{2}{|c|}{101.9} & \multicolumn{2}{|c|}{149.7} & \multicolumn{2}{|c|}{95.2} & \multicolumn{2}{|c|}{129.4} \\
\hline
\end{tabular}

* Fodder beet was fed as a mixed roughages at a ratio of 2:1 (2 parts tubers and 1 part leaves) on as fed basis with a dry matter content of 15.3, 13.8 and 14.5; $13.03 \%$ for beet tubers and leaves for the two trials, respectively. 
The metabolic body weight $\left(\mathrm{W}^{0.75}\right)$ of cows fed on beet and that fed on Abu 70 fodder during the two feeding trials were 95, 89 and 98.8, 99.8 $\mathrm{Kg}$, respectively. When dry matter intake was expressed as percentage of metabolic body weight, cows fed on beet forage consumed less DM than those maintained on the control fodder (Abu 70 forage) by approximately $32 \%$ and $28 \%$ in the first and second feeding trials, respectively.

Fig. (1) Shows the total DM intake per week for cows fed on the two forages during the two feeding trials. The straight line in the line graph illustrates the fixed amount of total dry matter intake of the two forages and was consistently lower for beet group compared to Abu 70 group.

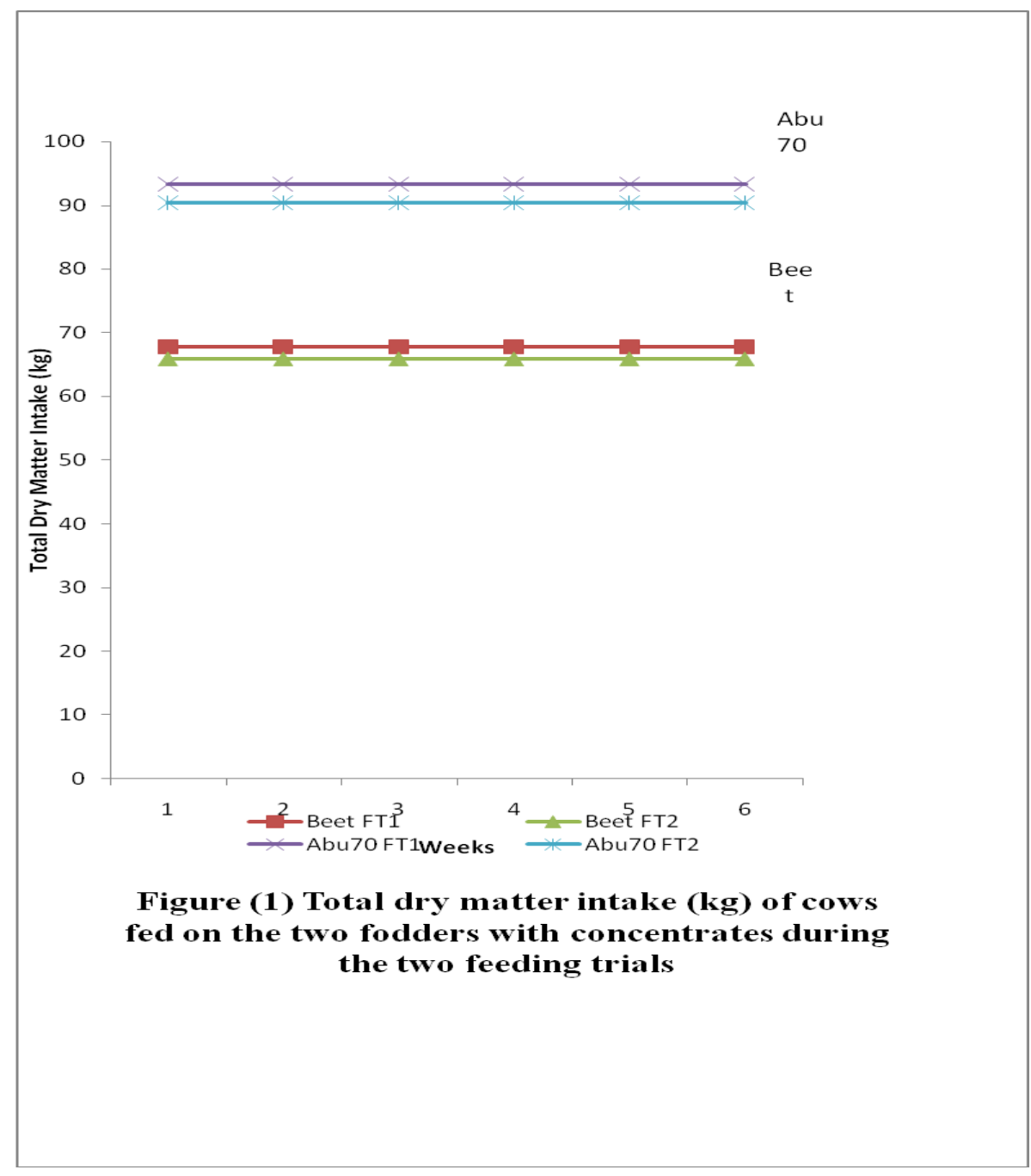


Milk yield and composition: The effects of dietary treatments on milk yield and composition of dairy cows are shown in Table (6). The results revealed that, cows fed on beet produced more average daily, weekly and total milk yield than those fed on Abu 70 in the second trial and vice versa for the first trial. Moreover, milk produced in the second feeding trial was more than that in the first one. The respective values of daily milk yield for the beet and Abu 70 groups were 7.42, 8.42 and 9.88, 8.92 $\mathrm{Kg}$ in the first and second trials, respectively. Milk yield was not significantly $(p>0.05)$ affected by the different fodders in both feeding trials. The fat and lactose $\%$ of milk from cows fed on beet were higher compared to that for cows fed on Abu 70 in the first trial and the reverse was true for the second trial. The test revealed that SNF \% of milk from beet was lower than that from Abu 70 by $0.16 \%$ in the first trial. However, in the second trial, SNF \% of beet milk was higher than Abu 70 milk by $0.11 \%$. The results indicated that milk fat, lactose and SNF \% were not significantly ( $>0.05$ ) affected by either beet or Abu 70 fodders during the two trials.

The weekly milk yield $(\mathrm{kg})$ of the cows fed on beet and that fed on Abu 70 during the two feeding trials is illustrated in Fig. (2). the peak milk yield per week from beet was reached in the first week $(55.8 \mathrm{~kg})$ and second week $(71.5 \mathrm{~kg})$ during the first and second feeding trials, respectively. The lowest weekly milk yield was recorded in the fifth week (46.8 and $67.1 \mathrm{~kg}$ ) during both trials. For cows fed on Abu 70 the highest milk yield per week was obtained in the $2^{\text {nd }}$ and $4^{\text {th }}$ week in trial 1 and in the first week during trial 2 . However, the lowest mean weekly milk yield was obtained in the $6^{\text {th }}$ week (55.36 and $56.1 \mathrm{~kg}$ ) during both feeding trials. Dairy Performance: Table (7) shows the dairy performance for the cows fed on the two fodders (beet and Abu 70) during the two feeding trials (2008 and 2009). The daily green forage intake of each group was $20 \mathrm{~kg}$. The daily DMI of beet and Abu 70 for the two trials were 2.95, 6.60and $2.80,6.30 \mathrm{Kg}$, respectively. Both groups were given $7 \mathrm{~kg}$ of commercial concentrate as fed corresponding to 6.73 and $6.61 \mathrm{Kg} \mathrm{DM}$ of concentrate during both feeding trials, respectively. The total dry matter intake of dairy cows fed on beet and those on Abu 70 ranged between $9.41-9.68 \mathrm{~kg}$ and $12.91-13.33 \mathrm{~kg}$, respectively. Comparing the two groups in DM intake (g) per $(\mathrm{kg})$ live body weight revealed that beet cows consumed far less amount of forage than those fed on Abu 70 and the respective values for beet and Abu 70 groups during the two feeding trials were 101.9, 144.7 and $95.2,129.4 \mathrm{~g} / \mathrm{Kg}$, respectively. The mean daily milk production of beet group ranged between $7.42-9.88$, and that of Abu 70 was $8.42-8.92 \mathrm{~kg}$, respectively. Milk quality results show similar values for both groups with milk from beet having 
Table 5: Proximate analysis (DM-Basis) and energy content of the dairy concentrate ration fed to dairy cows during the two feeding trials (2008 and 2009).

\begin{tabular}{|c|c|c|}
\hline \multirow{2}{*}{ Nutrient composition \% } & \multicolumn{2}{|c|}{ Commercial concentrate ration (D.16) } \\
\hline & 2008 & 2009 \\
\hline DM & 96.10 & 94.40 \\
\hline CP & 18.00 & 17.75 \\
\hline CF & 10.60 & 10.50 \\
\hline EE & 3.79 & 4.70 \\
\hline Ash & 9.09 & 9.25 \\
\hline NFE & 58.52 & 57.80 \\
\hline Calculated ME*(MJ/Kg DM) & 12.1 & 12.2 \\
\hline
\end{tabular}

ME* was calculated according to the equation given by MAFF (1975) as follows: ME $(\mathrm{MJ} / \mathrm{Kg} \mathrm{DM})=0.012 \mathrm{CP}+0.031 \mathrm{EE}+0.005 \mathrm{CF}+0.014 \mathrm{NFE}$

Table 6: Effects of feeding fodder beet versus Abu 70 on milk yield* and composition $^{* *}$ of dairy cows during the two feeding trials (2008 and 2009).

\begin{tabular}{|c|c|c|c|c|}
\hline \multirow{3}{*}{ Item } & \multicolumn{2}{|c|}{ Trial 1 (2008) } & \multicolumn{2}{|c|}{ Trial 2 (2009) } \\
\hline & \multicolumn{4}{|c|}{ Type of diets } \\
\hline & Fodder beet diet & Abu 70 diet & Fodder beet diet & Abu 70 diet \\
\hline Total Milk Yield (kg) & 311.66 & 353.74 & 415.36 & 374.90 \\
\hline Weekly Milk Yield (kg) & 51.94 & 58.96 & 69.23 & 62.48 \\
\hline Daily Milk Yield \pm SD & $7.42 \pm 2.04$ & $8.42 \pm 1.90$ & $9.88 \pm 0.92$ & $8.92 \pm 1.7$ \\
\hline $\begin{array}{l}\text { (kg/head/day) } \\
\text { C.V.\% }\end{array}$ & \multicolumn{2}{|c|}{24.92} & \multicolumn{2}{|c|}{14.52} \\
\hline$\%$ Fat \pm SD & $3.71 \pm 0.65$ & $3.10 \pm 0.96$ & $3.40 \pm 0.46$ & $3.81 \pm 0.34$ \\
\hline C.V. \% & \multicolumn{2}{|c|}{24.00} & \multicolumn{2}{|c|}{11.27} \\
\hline$\%$ Lactose \pm SD & $4.58 \pm 0.13$ & $4.56 \pm 0.52$ & $4.46 \pm 0.37$ & $4.56 \pm 0.05$ \\
\hline C.V.\% & \multicolumn{2}{|c|}{8.28} & \multicolumn{2}{|l|}{5.81} \\
\hline$\% \mathrm{SNF} \pm \mathrm{SD}$ & $8.35 \pm 0.24$ & $8.51 \pm 0.51$ & $8.73 \pm 0.30$ & $8.62 \pm 0.09$ \\
\hline C.V. \% & \multicolumn{2}{|c|}{4.73} & \multicolumn{2}{|c|}{2.52} \\
\hline
\end{tabular}

* No significant difference between forges on milk yield during the two trials

** No significant difference between forges on all milk quality components (fat, lactose and solid non-fat during the two trials

a butter fat $\%$ of $(3.40-3.71)$, lactose $\%(4.46-4.58)$ and SNF (8.35 8.73), while milk from Abu 70 had fat ( $3.1-3.81)$, lactose( 4.56) and SNF( $8.51-8.62)$. 


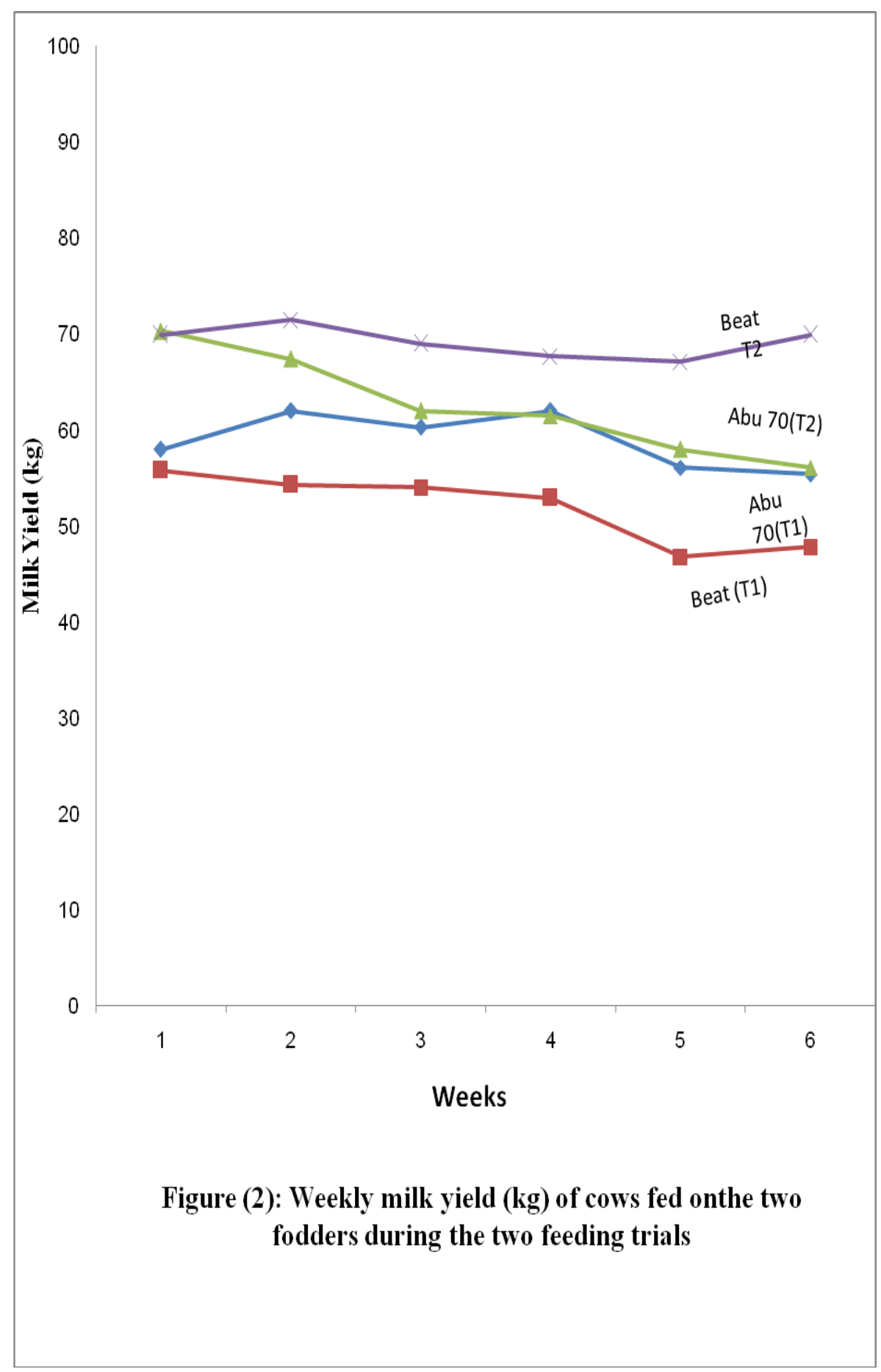


Table 7: Dairy performance (summary) for dairy cattle fed on beet versus Abu 70 during the two feeding trials (2008 and 2009).

\begin{tabular}{|c|c|c|c|c|}
\hline \multirow{3}{*}{ Item studied } & \multicolumn{2}{|c|}{2008} & \multicolumn{2}{|c|}{2009} \\
\hline & \multicolumn{4}{|c|}{ Types of forages } \\
\hline & $\begin{array}{l}\text { Beet } \\
\text { forage }\end{array}$ & $\begin{array}{l}\text { Abu } 70 \\
\text { forage }\end{array}$ & $\begin{array}{l}\text { Beet } \\
\text { forage }\end{array}$ & $\begin{array}{l}\text { Abu } 70 \\
\text { forage }\end{array}$ \\
\hline Feed intake of forage (as fed) $(\mathrm{kg})$ & 20 & 20 & 20 & 20 \\
\hline Feed intake of forage (DM. basis) $(\mathrm{kg})$ & 2.95 & 6.60 & 2.80 & 6.30 \\
\hline Concentrate intake (as fed) (kg) & 7 & 7 & 7 & 7 \\
\hline Concentrate intake (DM. basis) (kg) & 6.73 & 6.73 & 6.61 & 6.61 \\
\hline Total feed intake (as fed) (kg) & 27 & 27 & 27 & 27 \\
\hline Total feed intake (D M. basis) $(\mathrm{kg})$ & 9.68 & $13 . .33$ & 9.41 & 12.91 \\
\hline DMI g/kgw ${ }^{0.75}$ & 101.9 & 149.7 & 95.2 & 129.4 \\
\hline Mean daily milk production $(\mathrm{kg}) \pm \mathrm{SD}$ & $7.42 \pm 2.04$ & $8.42 \pm 1.90$ & $9.88 \pm 0.92$ & $8.92 \pm 1.7$ \\
\hline \multicolumn{5}{|l|}{ Milk quality } \\
\hline Butter fat $\% \pm \mathrm{SD}$ & $3.71 \pm 0.65$ & $3.10 \pm 0.96$ & $3.40 \pm 0.46$ & $3.81 \pm 0.34$ \\
\hline Lactose $\% \pm \mathrm{SD}$ & $4.58 \pm 0.13$ & $4.56 \pm 0.52$ & $4.46 \pm 0.37$ & $4.56 \pm 0.05$ \\
\hline Solids non-fiat $\% \pm \mathrm{SD}$ & $8.35 \pm 0.24$ & $8.51 \pm 0.51$ & $8.73 \pm 0.03$ & $8.62 \pm 0.09$ \\
\hline
\end{tabular}

Economics of Feeding: Table (8) presents the economics of feeding fodder beet compared to sorghum Abu 70 on milk yield of dairy cows under Khartoum conditions for the two feeding trials. The daily cost of green fodders (0.21 SDG for beet and 2.51 SDG for Abu 70) was calculated from the cost of $1 \mathrm{~kg}$ (green) of beet and Abu70 which was 0.01025 and 0.12545 SDG, respectively (Table 8), whereas the cost of concentrate (4.2 SDG in first trial and 4.9 SDG in second trial) was calculated by considering $1 \mathrm{~kg}=0.6 \mathrm{SDG}$ in trial 1 and $0.7 \mathrm{SDG}$ in trial 2 (in 2008 the cost of concentrate sack weighing50 kg was30 SDG and in 2009 it was 35 SDG). So, the total cost (SDG) of feed per day for the beet group and Abu 70 group during trial one and two were 4.41, 6.71 and 5.11, 7.41 , respectively. 
Table 8: Economics of feeding beet forage versus Abu 70 forage on milk production of dairy cows under Sudan conditions for the two feeding trials (2008 and 2009).

\begin{tabular}{|c|c|c|c|c|c|c|c|c|}
\hline \multirow{4}{*}{ Item } & \multicolumn{4}{|c|}{2008} & \multicolumn{4}{|c|}{2009} \\
\hline & \multicolumn{8}{|c|}{ Type of diet } \\
\hline & \multicolumn{2}{|c|}{ Fodder beet } & \multicolumn{2}{|c|}{ Abu 70 fodder } & \multicolumn{2}{|c|}{ Fodder beet } & \multicolumn{2}{|c|}{ Abu 70 fodder } \\
\hline & Beet & Conc. & Abu70 & Conc. & Beet & Conc. & Abu 70 & Conc. \\
\hline Feed intake as fed (kg) & 20 & 7 & 20 & 7 & 20 & 7 & 20 & 7 \\
\hline $\begin{array}{l}\text { Cost of feed/day as fed } \\
\text { (SDG) }\end{array}$ & 0.21 & 4.20 & 2.51 & 4.20 & 0.21 & 4.90 & 2.51 & 4.90 \\
\hline Total cost of feed SDG/day & \multicolumn{2}{|l|}{4.41} & \multicolumn{2}{|c|}{$\begin{array}{r}6.71 \\
34 \% * * *\end{array}$} & \multicolumn{2}{|c|}{5.11} & \multicolumn{2}{|c|}{$\begin{array}{r}7.41 \\
31 \% * * * *\end{array}$} \\
\hline $\begin{array}{l}\text { Average daily milk yield } \\
\text { (kg/head/day) }\end{array}$ & \multicolumn{2}{|c|}{7.42} & \multicolumn{2}{|c|}{8.42} & \multicolumn{2}{|c|}{9.88} & \multicolumn{2}{|c|}{8.92} \\
\hline $\begin{array}{l}\text { Revenue of milk sale } \\
(\mathrm{SDG})^{* *}\end{array}$ & \multicolumn{2}{|c|}{16.69} & \multicolumn{2}{|c|}{18.945} & \multicolumn{2}{|c|}{22.23} & \multicolumn{2}{|c|}{20.07} \\
\hline $\begin{array}{l}\text { Profit (SDG) (revenue - } \\
\text { cost) }\end{array}$ & \multicolumn{2}{|c|}{12.285} & \multicolumn{2}{|c|}{12.235} & \multicolumn{2}{|c|}{17.12} & \multicolumn{2}{|c|}{12.66} \\
\hline
\end{tabular}

* Cost of feed/day was calculated by costing $1 \mathrm{~kg}$ green fodder $=0.12545 \mathrm{SDG}$ and 0.01025 SDG for Abu 70 and Beet forages, respectively during the two trials (Table 9), where as for concentrate $1 \mathrm{~kg}=0.6$ SDG during trials 1 (2008) and 0.7 SDG during trial 2 (2009) due to the increased cost of sorghum grains and other components of the dairy concentrate mixture.

** Revenue for sale of milk was calculated by considering cost of $1 \mathrm{~kg}$ milk $=2.25$ SDG (1 lb of milk = $1 \mathrm{SDG})$.

*** Cost of feeding has decreased from 6.71 SDG for Abu70 to 4.41 SDG for Beet [the reduction in cost of feeding \%=6.71-4.41/ 6.71X 100=34 \%( during 2008).

**** The reduction in cost of feeding in 2009 was $7.41-5.11 / 7.41 \times 100=31 \%$ 
Table 9: Costs of fodders production/feddan SDG

\begin{tabular}{|c|c|c|c|c|}
\hline Item & \multicolumn{2}{|c|}{ Fodder beet* } & \multicolumn{2}{|c|}{ Fodder Abu $70^{* *}$} \\
\hline Seed & 20 & $1.94 \mathrm{~kg}$ & 217 & $78 \mathrm{~kg}$ \\
\hline Land preparation & 90 & & 80 & \\
\hline Planting & 50 & In holes & 20 & Broadcasting \\
\hline Irrigation & 220 & 11 irrigationX20 & 160 8irrigationX20 & \\
\hline Urea & 55 & $55 \mathrm{Kg}$ & 70 & $70 \mathrm{Kg}$ \\
\hline Super phosphate & 100 & $100 \mathrm{Kg}$ & - & \\
\hline Fertilizer application & 20 & & 10 & \\
\hline Weeding & 50 & & - & \\
\hline Thinning and filling & 20 & & - & \\
\hline Total cost & 625 & & 557 & \\
\hline & \multicolumn{4}{|c|}{ Cost of production of one ton } \\
\hline & \multicolumn{2}{|r|}{ Beet } & \multicolumn{2}{|c|}{$\begin{array}{r}\text { Abu 70 } \\
\end{array}$} \\
\hline $\begin{array}{l}\text { Green fodder yield } \\
\text { ton/fed }\end{array}$ & \multicolumn{2}{|r|}{60.97} & \multicolumn{2}{|c|}{4.44} \\
\hline Cost of 1 fed.SDG & \multicolumn{2}{|r|}{625} & \multicolumn{2}{|c|}{557} \\
\hline $\begin{array}{l}\text { Cost of one ton green } \\
\text { (SDG) }\end{array}$ & \multicolumn{2}{|r|}{10.25} & \multicolumn{2}{|c|}{125.45} \\
\hline Cost of kg green SDG & \multicolumn{2}{|r|}{0.01025} & \multicolumn{2}{|c|}{0.12545} \\
\hline
\end{tabular}

* Actual cost

** Estimated from EL-Selait Agricultural project

Daily feeding costs were reduced by $34 \%$ during 2008 and $31 \%$ during 2009, respectively. The revenue of milk sale was obtained by multiplying the price of $\mathrm{lb}$ of milk (SDG) by average daily milk yield in $\mathrm{lb}$ $(1 \mathrm{~kg}=2.25 \mathrm{lb})$. The profits (SDG) of milk sale from beet were 12.285 SDG and 17.12 SDG and that of Abu 70 were 12.235 SDG and 12.66 SDG. Fodder beets gave higher profit over sorghum Abu 70 during both seasons.

\section{DISCUSSION}

Chemical composition of forages: Nutrient composition of forage is useful in management practices and formulation of rations for livestock.

The present study showed that beet tubers contain higher amount of nitrogen free extract, lower crude protein, crude fibre and ash than the leaves but, they were similar in ether extract percentage. These findings are in line with those reported by Nadaf et al. (1998a) working on three fodder beet cultivars in Oman. They found that tubers were rich in starch (NFE) and lower in crude fibre as compared to the leaves. Moreover crude protein (CP) content of the leaves ranged between 14 and 15.8, while the tubers contained between 4.5 and $9.8 \%$ of crude protein. Also, they showed that leaves had higher ash content (25-28\%) as compared to the tubers. Both 
roots and leaves contained less dry matter than fodder sorghum Abu 70. The results were in agreement with the finding of Nadaf et al. (1998a) who concluded that dry matter content of fodder beet leaves and tubers were lower than that of Rhodes grass (20-25\%).

Crude protein $(\mathrm{CP})$ and ash contents of the beet leaves were higher than that of fodder Abu 70 during both trials. Similar results were found by Nadaf et al. (1998a) who reported higher crude protein content of three cultivars of fodder beet leaves compared to Rhodes grass. Also, fodder sorghum was higher in crude fibre (CF) and nitrogen free extract (NFE) than beet leaves; lower in NFE than beet tubers and similar to both beet leaves and tubers in ether extract (EE). The calculated metabolizable energy (ME) of beet and sorghum Abu70 in ascending order is: beet leaves (9.8), fodder sorghum (11) and beet tubers (12) MJ/kg DM. These results with respect to Abu70 grass were in agreement with those reported by Ellis (1981) who reported that sorghum cultivar Abu 70 contains 2\% EE, 38.6\% $\mathrm{CF}$ and $8.96(\mathrm{MJ} / \mathrm{kg} \mathrm{DM}) \mathrm{ME}$. Also, Ibrahim (2005) found that fodder sorghum Abu 70 had $13.6 \%$ ash and $46.2 \%$ soluble carbohydrates.

Fodder beet exceeded fodder sorghum in calcium and phosphorus contents. Ellis (1981) reported that sorghum Abu 70 contains 0.44 and $0.01 \%$ of calcium and phosphorus, respectively.

Most of the requirements for $\mathrm{Ca}, \mathrm{P}, \mathrm{K}, \mathrm{S}, \mathrm{Mg}$ and the trace elements $\mathrm{Co}, \mathrm{Mn}, \mathrm{Zn}, \mathrm{Fe}$ and Se may be provided from the leafy forage consumed by dairy cattle (NRC, 1982). But, in general, forages do not contain adequate levels of $\mathrm{P}, \mathrm{Ca}, \mathrm{Na}, \mathrm{Cl}, \mathrm{I} ., \mathrm{Mg}, \mathrm{Fe}$ and $\mathrm{Zn}$ for satisfactory livestock production, particularly interest $\mathrm{Ca}$ and $\mathrm{P}$ (Shenk and Barnes, 1985). So, extra supplements of $\mathrm{Ca}$ and $\mathrm{P}$ are needed. This is supplied by the addition of limestone and dicalcium phosphate to the concentrate mixture (Conrad and Martz, 1985).

\section{Performance of Dairy animals:}

Feed intake: The daily dry matter intakes (DMI) of beet (leaves plus tubers) were 2.95, 2.80 and that of sorghum Abu70 were 6.6, $6.30 \mathrm{~kg} / \mathrm{cow}$ during the first and second feeding trial, respectively. Dry matter intake was considerably lower for the beet group, obviously due to the lower dry matter content of the Beet $(13.03-15.3 \%)$ than that of sorghum $(31.5-$ $33.0 \%)$.

In the present trial, cows fed on beet were given $13.3 \mathrm{~kg}$ tubers (as fed) and this is consistent with reported daily amount of $10-30 \mathrm{Kg}$ (Ibrahim, 2005).

The daily dry matter intake of fodder beet in this study was lower but, that of grasses was higher than that reported by Mogensen and 
Kristensen (2003) for Danish Holstein with $603 \mathrm{~kg}$ mean live weight (3.6 $\mathrm{kg}$ DM from fodder beet with a total intake of $21.4 \mathrm{~kg}$ and $3.4 \mathrm{~kg}$ DM from barley with a total intake of $21.4 \mathrm{~kg}$ ).

The commonly fed amount of fodder beet was $20 \mathrm{~kg}$ of fodder beet (Hoden et al., 1988), between 0 and 4kgDM per day per animal (Dulphy et al., 1990).

The dry matter intake of fodder sorghum Abu70 in this trial was lower than those obtained by Ahmed (1995) (9.78 kg/day) when he investigated the feeding value of Abu 70 hay on sustaining yield and quality of milk from local dairy cattle (a mixture of Kenana and Butana types) in their early lactation. Moreover, the total dry matter intake (Abu 70 hay and concentrate) was $10,76 \mathrm{~kg} /$ day. He added that the dry mater intake ranged between $2.9-3.2 \%$ of the body weight for local animals.

The variation in daily dry matter intake may be attributed to the breed type, age, weight, forage nutritive value and environmental factors like temperature and relative humidity (El Hag, 2008).

Dinius (1978) concluded that cattle consumed daily about $2.8 \%$ of their body weight from high quality forage dry matter (DM), but slightly less than $2.0 \%$ for concentrates dry matter.

Milk yield and composition:The increase in milk yield recorded for the second trial compared to the first one may be attributed to variation between seasons.

There were no significant $(\mathrm{P}>0.05)$ differences in milk yield between cows given the two fodders (beet and Sorghum). Similar results were obtained by Nadaf et al. (1998a) in Oman, who compared feeding value of fodder beet to Rhodes grass in milk production.

The present values of overall daily mean milk yield from beet and sorghum Abu 70 were similar $(8.7 \mathrm{~kg})$, but was higher than those reported by Nadaf et al. (1998 a) working on beet versus Rhodes grass (7.7 and 7.3 $\mathrm{Kg}$, respectively). In both studies, the milk yield was almost similar with respect to feeding beet and Abu 70 or Rhodes grass. Also, the average milk production per day of crossbred cows (Friesian/Kenana) fed on Abu70 was $(9.1 \mathrm{~kg})$ reported by Ibrahim (2008) in Sudan, was almost similar to the present results of fodder sorghum $(8.7 \mathrm{~kg})$.

In the first trial, milk fat $\%$ from beet was higher than that of $\mathrm{Abu}$ 70 forage and vice versa in the second trial. The same trend was observed for lactose $\%$. This difference may be attributed to lower milk production from cows in the beet treatment observed in the first experiment, and its negative correlation with the fat $\%$ was also confirmed by Vinogradov et al. (1983) who stated that the major milk components were lower in 
cows with high milk yield. However, solids non-fat followed an opposite trend.

The results concerning the insignificant $(p>0.05)$ effect on milk components in this work were in full accordance with the findings reported by Mogensen and Kristesen (2003) who claimed that, milk fat content was not significantly differed between the two dietary treatments of fodder beet and Barely.

Moreover, results of this study agreed with those obtained by Eriksson et al. (2004) who reported that neither fat nor lactose concentrations were altered by diet of fodder beet or barley in lactating Swedish red and white dairy cows.

The average milk fat percentage from beet and sorghum fodder (3.56 and 3.46\%) were lower than those reported by Mogensen and Kristensen (2003) for fodder beet and barely (4.41 and 4.47\%) in Denmark working on Danish Holstein. This difference might have been due to interactive effect between the genetic and environmental factors (Abd EL Rahman and Ahmed, 2005).

Cost of feeding on beet was less than that of Abu 70 although the cost of production of beet from one feddan exceeded that of Abu 70 .This is possibly because the beet outyielded Abu 70 .

The overall results demonstrated a better feeding value of fodder beet and profitable dairy performance under conditions of the study during the winter season compared to the classical Abu70 forage. These results will definitely recommend forage beet as potential dairy forage to fill in the gap of forage production during late winter and early summer season, under the conditions of the Khartoum State.

\section{CONCLUSIONS and RECOMMENDATIONS}

- Beet had higher amount of crude protein, nitrogen free extract, calcium and phosphorus than Abu 70 which had higher dry matter and crude fiber.

- Dry matter intake of cows $(\mathrm{Kg} / \mathrm{head} /$ day $)$ fed on beet $(2.88 \mathrm{Kg})$ was less than that fed on fodder Abu $70(6.45 \mathrm{Kg})$ simply due to difference in dry matter percentage.

- Milk yield and its composition of the two groups of cows were not significantly different.

- Fodder beet is cheaper and more profitable compared to Abu 70.

- Results have clearly demonstrated the efficiency of feeding forage beet to dairy cattle compared to traditional Abu 70, due to more profitable milk production and cheaper cost of feeding without having any negative 
effect on either milk yield or composition. Therefore forage beet is recommended as ration forage for dairy animals in Khartoum State.

- During the trial the amount for roughage (beet and Abu 70) was fixed at about $20 \mathrm{~kg}$ per day and the amount of concentrate at $7 \mathrm{~kg} / \mathrm{head} /$ day. It was noticed that cows fed on forage beet frequently complete and cleaned their feeding troughs from the beet in about an hour of time during both feeding trials, whereas cows fed on Abu 70 continued to eat their roughage overnight. This reflects that fodder beet was highly palatable and desired by the dairy cows, besides the difference in dry matter intake due to different dry matter percentages. Accordingly it is recommended to feed only $7 \mathrm{~kg} /$ day of Abu 70 for the dairy cattle and ad libitum amount of the forage beet to obtain profitable milk production.

Acknowledgment: We acknowledge with great gratitude the Scientific Research Council-Sudan University of Science and Technology for financing this research.

\section{REFERENCES}

A.O.A.C. (1984): Official methods of analysis, $14^{\text {th }}$ edition Association of Analytical Chemistry, Washington, D.C.

A.O.A.D. (2002): Study of the feasibility of forages production and manufacturing integration in Arabic region. Khartoum, Sudan.

Abdallah, E.F. and Yassen, A.A. (2008): Fodder beet productivity under fertilization treatments and water augmentation. Australian journal of Basic and Applied Sciences, 2 (2): 282-287.

Abd-Alrahman, A.M. and Ahmed, S.S. (2005): Principles of animal production science. $1^{\text {st }}$ edition. Publisher: Open University of Sudan, 388p.

Abou El-Hassan, A.; El-Samman, S.; Radwan, A. and Stino, G. (1971): The nutritive value of Fodder beet under U.A.R. conditions. Journal of Animal Production, 11: 233-234.

Abuswar, A.O. (2005): Forage production in the Sudan (in Arabic), Khartoum University Press, Sudan.

Ahmed, A.A. (1995): The effect of forage-sole diets on yield and quality of milk from local dairy cattle. M.Sc. Thesis, Faculty of Animal Production, University of Khartoum, Sudan.

Animal Wealth Bank (2003): Annual report of livestock. Khartoum, Sudan. Anonymous (1994): Annual Reports of Agricultural Research, Department of Agricultural Research, Ministry of Agriculture and Fisheries, Sultanate of Oman. [C.F. Nadaf, S.K., Ibrhaim, Y.M., Akhtar, M., 
El Hag, M.G. and Al-Lawati, A.H. (1998a). Performance of Fodder beet in Oman. Annals of Arid Zone, 37 (4): 377-382].

Beever, D.E.; Offer, N. and Gill, M. (2000): The feeding value of grass and grass products. In: Grass its Production and Utilization. $3^{\text {rd }}$ edition. Blackwell Science Limited, London, pp. 140-195.

Chatterjee, B.N. and Das, P.K. (1989): Forage Crop Production: Principles and Practices. Oxford and IBH Pub. Co. Pvt. Ltd., New Delhi, 450 p. [C.F. Nadaf, S.K., Ibrhaim, Y.M., Akhtar, M., El Hag, M.G. and Al-Lawati, A.H. (1998a). Performance of Fodder beet in Oman. Annals of Arid Zone, 37 (4): 377-382].

Conard, H.R. and Martz, F.A. (1985): Forage for dairy cattle. In: Forage: The Science of Grassland Agriculture. $4^{\text {th }}$ edition. The Iowa State University Press, U.S.A., pp. 550-559.

Dinius, D.A. (1978): Conserved pasture crop for finishing beef cattle. Journal of Dulphy, J.P., Rouel, J. and Bony, J. (1990). Fodder beets in complement of grass silage for dairy cows. INRA Prod. Anim, 3 (3): 195-200.

Dulphy, J.P.; Rouel, J. and Bony, J. (1990): Fodder beets in complement of grass silage for dairy cows. INRA Prod. Anim, 3 (3): 195-200.

EL-Hag, M.G. (2008): Principles of Animal Nutrition and Applied Nutrition for Ruminants. Coins Sudan Press Company limited.237p

Ellis, N. (1981): The Nutrient Composition of Sudanese Animal Feeds, Bulletin 1: North and Central Sudan. Central Animal Nutrition Laboratory, Kuku, Khartoum N. Democratic Republic of Sudan, Ministry of agriculture, Food and Natural Resources.

Erikson, T.; Murphy, M.; Ciszuk, P. and Burstedt, E. (2004): Nitrogen balance, microbial protein production and milk production in dairy cows fed Fodder beets and potatoes, or barley. Journal of Dairy Science, 87: 1057-107

Gomez, K.A. and Gomez, A.A. (1984): Statistical procedures for agricultural research. $2^{\text {nd }}$ edition, john Willy and sons Inc. New York. 680p.

Hoden, A.; Marquis, B. and Delaby, L. (1988): Fodder beets with maize and red clover silages for dairy cows. INRA Production Animals, 1(3):165-169

HTTP://www.ars-grin.gov/cgi-bin/npgs/html/taxon (1987).

HTTP://www.biologie.uni-hamburg.de/b-

online/schaugaren/varalba/fodder-beet (2006). 
Hussein, M.A. (2008): Milk production and marketing in the Sudan a study of Khartoum and Gezira States, Ph.D. Thesis, Faculty of Agriculture, University of Khartoum, Sudan.

Ibrahim, Y.M. (2005): Ranges and forage (In Arabic). Dar Azza for Publication, Khartoum, Sudan, 300p.

Ibrahim, Z.O. (2008): Effect of feeding Rhodes grass (Chloris gayana) on milk production and its composition of dairy cows. M.Sc. Thesis, Faculty of Agricultural Studies, Sudan University of Science and Technology, Sudan.

Kambal, A.E. (1983): Comparative Performance of some varieties of sorghum,maize and pearl millet for forage production in different seasons.Sudan Agricultural Journal 10: 46-60.

Khair, M.A.M.; Salih, SH.A.; Elhag, F.M.A. and Eltayeb, E.I. (2003): Dry Matter Yield and Quality of Some Winter Sown Forage Crops in the Sudan Gezira.University of Khartoum Journal of Agricultural Science, 15(2) 204-219.

Kiely, P.O.; Moloney, A.P. and Meagher, J. (1991): Ensiling and feeding whole-crop Fodder beet. Landbauforchung-voelkerode Sonderheft, 123: 269-272.

MAFF (Ministry of Agriculture, Fisheries and Food) (1975): Energy Allowances and Feeding Systems for Ruminants. Technical Bulletin 33 HMSO- London: ISBN 011240894 X

Mahesh, L. (1999): Human labor absorption in dairy. Evidence for Kernl village of Hyryna. Indian Journal of Agricultural Economic, XL 2: 150-158 [C.F. Elbaloola, R.Y.A. (2005). The economics of milk production in El Guneid area, Sudan. M.Sc. Thesis, Faculty of Agriculture, University of Khartoum, Sudan].

Martin, J.H.; Leonard, W.H. and Stamp, D.L. (1976): Principles of field crop production. Third edition. MacMillan Publishing Co., Inc., New York.1118p.

Mogensen, L. and Kristensen, T. (2003): Concentrate mixture, grass pellets, Fodder beets, or barley as supplements to silage ad libitum for high-yielding dairy cows on organic farms. Animal Science, 53: 186-196.

Mstat, V.4. (1986): A microcomputer program for the design management and analysis of agronomic research experiments. Michigan State University, USA.

Nadaf, S.K.; Ibrhaim, Y.M.; Akhtar, M.; El Hag, M.G. and Al-Lawati, A.H. (1998a): Performance of Fodder beet in Oman. Annals of Arid Zone, 37 (4): 377-382. 
Shalaby, A.S.; Rammah, A.M.; Abdul-Aziz, G.M. and Beshay, M.G. (1989): Fodder beet, a new forage in Egypt. 1. Productivity and the chemical analysis of some Fodder beet (Beta vulgaris L.) cultivars sown at different locations in Egypt. In proceedings of the third Egyptian British Conference on Animals, fish and poultry production. Alexandria, Egypt, 13: 133-143.[C.F. Nadaf, S.K., Ibrhaim, Y.M., Akhtar, M., El Hag, M.G. and Al-Lawati, A.H. (1998a). Performance of Fodder beet in Oman. Annals of Arid Zone, 37 (4): 377-382.

Shenk, J.S. and Barnes, R.F. (1985): Forage analysis and its application. In: Forage the Science of Grassland Agriculture. Fourth edition. Pp. 445-451, Iowa State University Press, Ames, Iowa, USA.

Vinogradov, V.N.; Churbakov, Yu.A.; Serbinovich, O.D. and Shemelesa, L.B. (1983): The improvement of black pied cattle by crossing with Holstein-Friesians. Animal Bread Abstracts 51: 5914. 